\title{
Research on the Higher Education Management Theory Framework Optimization and Practice under the Internet Background
}

\author{
Qi Yanchun \\ Gannan Medical University, \\ Ganzhou, Jiangxi, 341000 China
}

\begin{abstract}
In this paper, we conduct the basic research on the higher education management theory framework optimization and practice under Internet background. Under background of globalization, the world in the development of higher education management reform and marketization, enterprise trend has become increasingly highlighted. The transformation and development of higher education of the higher education management mode and social many basic relations between the sharp changes of demands for knowledge changes have a close relationship, the pursuit of performance management and evaluation as the main measure of university development and quality. Modern university's core mission lies in the responsibility for knowledge, rational knowledge to reveal the real world, with the construction of rational knowledge to guide benign and orderly society. Our research combines basic features of the Internet to form the novel paradigm for education which is meaningful.
\end{abstract}

Keywords- Higher Education, Management, Theory Framework, Internet Background.

\section{Introduction}

In the era of knowledge economy, the fundamental power of economic growth is the progress of the science and technology. Play the leading role of science and technology progress of this task is the human and intellectual resources, and institutions of higher learning is definitely the most important source of intellectual resources, so the quality of the future intellectual resources provided by colleges and universities, the student quality also is particularly important. Education quality management for individual students and the education system in colleges and universities use to the society as a whole is important in many aspects. In a sense, university education quality management is the process of the game process of the parties for their own interests, as using the game theory method to analyze the interests of the parties request, the behavior direction and the education quality affecting factors, help to improve the quality of education [1-3].

According to the literature review, the primary drawbacks of the current management framework can be summarized as the follows. (1) Too much emphasis on the role of teachers, and ignored the students' subject position. At present most of the institutions of the higher learning in the education management work, can't distinguish between the teacher and the student's status, the school too much on the teacher's position in the process of education, and even some people think that the teacher's teaching is the whole of the school teaching work. (2) The lack of scientific education management. Exist in many modern colleges and universities education administration and teaching work of phase separation, leading to the teacher knowledge of education management is not deep, the lack of the concept of education management. Even part of the teachers in colleges and universities will think the teacher's main job is to make teaching work, do the good job of the teaching at the same time that also completes the education management work. This kind of education thought, the college students in college didn't get a complete education. (3) Education management mode is single. With deepening of the reform of education, as many universities merger, enrollment expansion, this makes the education teaching management in colleges and 
universities face great pressure management shortcomings.

School management is a specific education means any operation environment as the specific means of quality education can only be run on the platform and achieves function and value. But traditional education management mechanism and management system and quality education that still exists the inevitably conflict between ideas and the measures, so the traditional school management is an urgent need in the perspective of quality education to establish new management system and mechanism of quality-oriented education. People-oriented education management idea, human factor is considered, and the talent is the fundamental management, and gives prominence to characteristics of personality, try to meet reasonable needs of various people. Based on people's thoughts, behaviors, take effective means to tap people's subjective initiative, as enthusiasm and creativity. Managers that the traditional way to orders have not adapted to the requirements of modern management, and replaced by common goals, careful and meticulous ideological mobilization, and to lead by the precept, eventually to be managers could accept education as shown in the following figure [4].

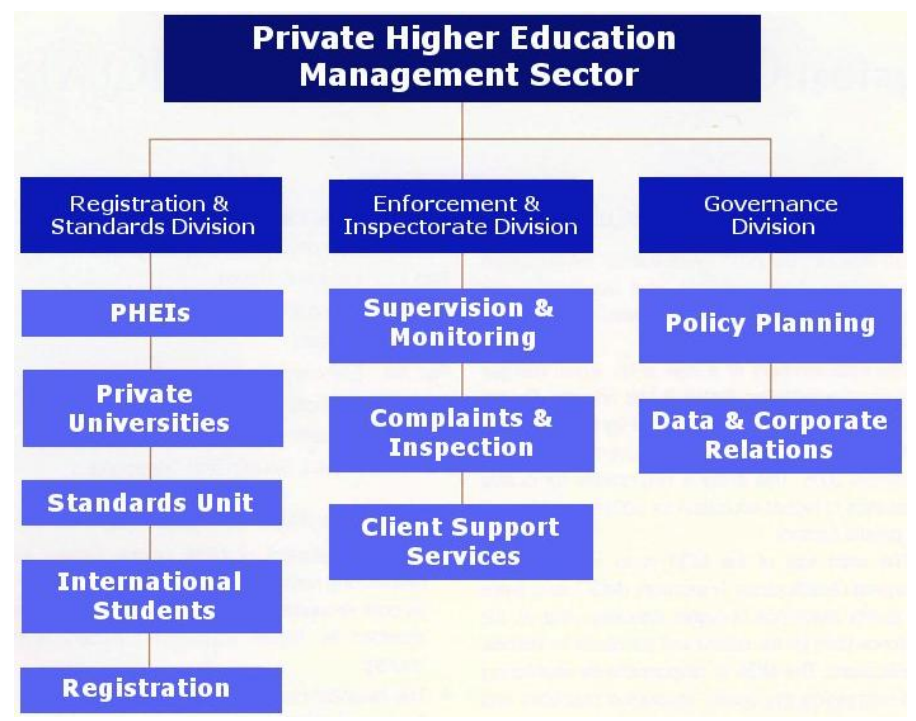

Figure 1. The General Organization and Architecture of the Higher Education Management

In this paper, we conduct basic research on the higher education management theory framework optimization and practice under the Internet background. Our country's higher vocational education at present is still in its primary stage of development, a lot of problems in research and the exploration period. Higher vocational education to improve the teaching quality, as strives for the survival by the quality, to the quality strives for the development. By developing higher vocational education, better serve the local economy, and to maximize meet the needs of the local economic construction as the school standards, to serve the economic and the social contribution to the development of the school, working hard to blaze a trail of school-running characteristics, professional characteristics, cultivate students have the special features of the new way of the higher vocational education. In the following sub-sections, we will discuss the corresponding issues in detail.

\section{The Proposed Methodology}

The Principles of Teaching Management. With the economic globalization and rapid development of the science and technology, 
international competition in the overall national strength is becoming increasingly fierce, in the final analysis while competition is the talent competition of comprehensive national strength. The institutions of higher learning is to cultivate high-quality talents in the field of construction, construction of teaching management team is an important part of the own construction of colleges and universities, and ensure the normal working of teaching work and the basic guarantee for the teaching quality improved steadily. At present, with the expansion of the teaching, the task of teaching management, teaching management informatization is a new type of teaching management mode that can effectively improve the management efficiency of teaching management and quality management, more and more get the attention of managers. How to carry out teaching management informatization is an important topic of current college teaching management attention. Therefore, research of teaching management informatization construction has important practical significance. The corresponding components of the management system can be categorized as the follows.

- The basic construction of teaching management. Teaching basic construction is to guarantee the quality of teaching is the most important basic construction that according to the school development planning, overall arrangement with the careful organization [5].

- Operation and management of teaching. Teaching management is the most core of teaching management, the most important part. The purpose of the operation and management of the teaching is fully arousing within the system of teaching resources, according to the teaching plan to implement the teaching activities.

- Teaching quality management and evaluation. Teaching quality is lifeline of the development of the school. Departmental teaching management including the content of teaching quality management and evaluation, examination, listening to lectures, teacher's teaching quality through implementation of teaching evaluation, teaching supervision to guarantee education quality of the primary teaching activities.

- Teaching plan management. Professional teaching plan is the guidance document of school personnel training goals and it reflects school quality requirements for all kind of professional talents as the main basis is to organize teaching activities. Formulating and revising teaching plan is to cultivate high-quality talents to improve the teaching level is an important link.

Classroom teaching management is in classroom teaching in process of long-term development, and gradually formed a kind of orderly, specification requirements, is the result of interaction of many factors, its function play not produced naturally that need long-term accumulation and construction. Its essential characteristics is to make the ordering of classroom teaching, standardization is affecting the efficiency of class activity and quality of the important factors.

The Higher Education Management. The fierce competition in the global education market, as the complex environment and continuing economic shocks, pose a lot of pressure to the survival of the education institutions, for they have to focus on for their lives to take some strategies.

Higher education policy is the government management of higher education a strong guarantee. A clear boundary to a correct understanding of the policy of the higher education policy goals, grasp the essence, clear responsibility assignment policy plays an important role, is helpful to realize the goal of 
higher education. The figure two demonstrates the related concepts [6-7].

Director-General

Department of Higher Education

Deputy Director-Genera

Public Higher Education

Management Sector
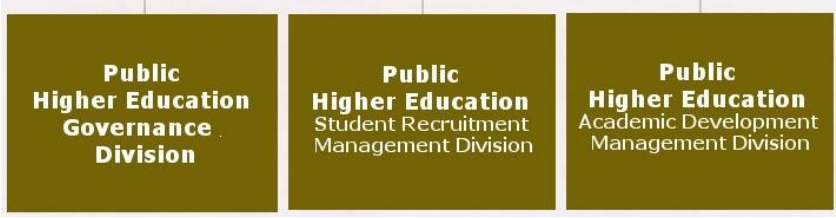

Figure 2. The Higher Education Management

\section{Architecture}

As specific education policy of higher education refers to the country or party in order to achieve higher education target and norms and management of higher education administrative rules. Higher education policy has generally the commonality of the public policy as has its unique characteristics, namely the target of the fuzziness and the complexity of the conflict, execution and tardy, tardy and long-lasting effect, and changes in the environment and multiplicity. Therefore, we suggest the listed suggestions. (1) Development of higher education. In higher education, the development of many colleges and universities has own characteristics, therefore, in order to promote school construction and development of higher education, colleges and universities should actively encourage expanded influence of school-running characteristics. (2) Pay attention to the teaching and scientific research. At present, some colleges and universities in developing problems, with the development of colleges and universities teaching, scientific research in the phase separation has a certain relationship, which affect the teaching quality and the students. (3) Improve the quality of higher education schools. To promote the development of the higher education, the most fundamental is to improve the quality of school-running, fundamentally realizes the higher education in China.
The Internet and Education. With the continuous development of the Internet and improvement of information technology has entered every aspect of society, of course also permeated every aspect of education. The multimedia network teaching environment of the Internet has a variety of features to optimize teaching to make students as the center, based on resources and communication cooperation teaching method and it has the advantages of traditional teaching methods.

The Internet is a huge information source, we can on Internet, through research from information in the ocean of knowledge, the learning community on the Internet to build technical support through the communication between members of the learning community, promote each other between learning and so on, these ways and methods, are learners as the center. The traditional teaching, the students are the passive recipients of knowledge, how to let the students change from passive to active status, so as to build their own knowledge, to solve practical problems that is a very critical problem. As the countermeasures, we propose the listed perspectives. (1) On the Internet, there is no unified teaching material, no unified process. Every learner can refer to the own characteristics, and according to their convenient time freely to choose the appropriate learning resources from the Internet, according to the suitable for their own way to learn. (2) The Internet for education out of the campus, towards society provides a strong technical support, this is a process of basic education socialization, informatization. Education will gradually from the school to family, community and country, to any of the information technology popularization. (3) Teachers teach in traditional teaching, basic it is described in language, which makes learners difficult to quickly grasp, and the emergence of the Internet has changed the situation. Internet delivered all over the world such as young, research institutes, libraries and other kinds of information resources, and become an 
inexhaustible with the inexhaustible mass information repository. (4) It can be downloaded on the Internet, learners not only the teacher's lecture notes, as assignments, and other related resources, as still can ask in the near and the teacher, the teacher will quickly solve problems of learners, and gives relevant background knowledge and learning materials, learning to get twice the result with half the effort [8].

The Future of College Education. Comprehensively improve the level of education and students training quality is a complicated system project, all aspects need to work on, at the same time improve the quality of students is the process of a dynamic process, constantly improve and adjust the society, colleges and students are the three aspects of this process participants.

College teaching is the core of talent training, the teaching as the main means of talent cultivation in colleges and universities is needless to say, in addition, college students work in the aspect of talent cultivation also plays a very important role, especially in cultivating college students' social and the personality education plays an unique advantages, at the same time the student work is to provide the security for the orderly conduct of teaching activities. Quality education is the cause of education in China of a far-reaching and involved in all aspects of the social system engineering that is the broad masses of young students grow up, employment, entrepreneurship and the urgent need of education and practice is higher education to adapt to the economic and social development for human resources development, especially the youth human resources development of urgent need.

As a result, the education of colleges and universities should change the educational ideas, guided by concept of quality education, to develop college students on human resources, actively construct the new personnel training mode, the combination of professional education and quality education, tightly around the diathesis developing training guidance with career planning, to establish evaluation system and strengthening the campus identity four link develop project of cultivating college students' comprehensive quality, promoting students' quality education, especially the main channel to further expand and deepen teaching helps to cultivate college students' career employment ability.

\section{Conclusion}

In this paper, we conduct the basic research on the higher education management theory framework optimization and practice under the Internet background. Higher education for the talents cultivation, social stability and national development has a positive meaning, conveying a large number of talents for the society every year. But in the development of the recent years, higher education has some problems, such as mechanism of higher education, higher education teaching management, such as higher education personnel training problems. In view of the problems arising from the development of the higher education, combined with the specific situation, improve the development of the higher education quality, higher education characteristics, pay attention to teaching and scientific research and three aspects of countermeasures were put forward. In the future, we will conduct more in-depth analysis on the optimization of the approaches theoretically.

\section{References}

[1] Gibb, Allan, Gay Haskins, and Ian Robertson. "Leading the entrepreneurial university: Meeting the entrepreneurial development needs of higher education institutions." Universities in Change. Springer New York, 2013. 9-45.

[2] Parker, Lee D. "From privatised to hybrid corporatised higher education: a global financial management discourse." Financial 
Accountability \& Management 28.3 (2012): 247-268.

[3] Foo, K. Y. "A vision on the role of environmental higher education contributing to the sustainable development in Malaysia." Journal of Cleaner Production 61 (2013): 6-12.

[4] Decramer, Adelien, et al. "External pressures affecting the adoption of employee performance management in higher education institutions." Personnel Review 41.6 (2012): 686-704.

[5] Jiang, Nan, and Victoria Carpenter. "A case study of issues of strategy implementation in internationalization of higher education." International Journal of Educational Management 27.1 (2013): 4-18.
[6] Teichler, Ulrich. "Academically ambitious and relevant higher education research: the legacy of the Consortium of Higher Education Researchers." European Journal of Higher Education 3.3 (2013): 242-254.

[7] Venkatesh, Vivek, Anne-Marie Croteau, and Jad Rabah. "Perceptions of effectiveness of the instructional uses of technology in higher education in an era of Web 2.0." System Sciences (HICSS), 2014 47th Hawaii International Conference on. IEEE, 2014.

[8] Rae, David, et al. "Enterprise and entrepreneurship in English higher education: 2010 and beyond." Journal of Small Business and Enterprise Development 19.3 (2012): 380-401. 